\title{
Net Nutrient Uptake in the White River, Northwest Arkansas, Downstream of a Municipal Wastewater Treatment Plant
}

\author{
Brad W. Hufhines ${ }^{1}$, Kristofor R. Brye ${ }^{2}$, Brian E. Haggard ${ }^{3}$, Robert Morgan ${ }^{4}$ \\ ${ }^{1}$ Environmental Technician, Beaver Water District, Lowell, USA; ${ }^{2}$ Department of Crop, Soil, and Environmental Sciences; Univer- \\ sity of Arkansas, Fayetteville, USA; ${ }^{3}$ Department of Biological and Agricultural, Engineering, University of Arkansas, Fayetteville, \\ USA; ${ }^{4}$ Environmental Quality Manager, Beaver Water District, Lowell, USA. \\ Email: kbrye@uark.edu
}

Received November $18^{\text {th }}, 2010$; revised January $8^{\text {th }}, 2011$; accepted February $14^{\text {th }}, 2011$.

\begin{abstract}
Wastewater treatment plays a crucial role in preserving water quality in receiving streams; however, continuous nutrient enrichment can diminish the retention capacity of rivers. The objectives of this study were to evaluate the effects of wastewater treatment plant effluent and river discharge on water chemistry and determine the retention efficiency of nutrients added in the effluent along a 6.1-km reach of a 5th-order stream in the Ozark Highlands of northwest Arkansas. From 2006 through 2007, effluent discharge increased river nitrite, soluble reactive P (SRP), and total organic C (TOC) and conductivity. As river discharge increased, dissolved oxygen (DO) and turbidity increased, but water temperature, conductivity, and TOC decreased. Net nutrient uptake lengths were inconsistent for $\mathrm{NO}_{3}-\mathrm{N}, \mathrm{NH}_{4}-\mathrm{N}$, and SRP. Results indicated that the fluvial channel acted as both a sink and a source of $\mathrm{NO}_{3}-\mathrm{N}$ and SRP, but the channel always acted as a sink for $\mathrm{NH}_{4}-\mathrm{N}$ with a significantly positive retention coefficient that indicated only $12 \%$ of added $\mathrm{NH}_{4}-\mathrm{N}$ was retained in the study reach. The effluent discharge increased the concentrations of seven water quality parameters and it appears the long-term enrichment has rendered the immediate-downstream reach ineffective as a nutrient sink. Nutrients added in the effluent were generally transported with little to no uptake or transformation, thus river chemical concentrations beyond the study reach have likely been influenced by this effluent discharge.
\end{abstract}

Keywords: Streamflow, Point-Source Pollution, Nutrient Spiraling, Source-Water Protection

\section{Introduction}

Water quality issues in the Ozark Highlands region of northwest Arkansas, southwest Missouri, and northeast Oklahoma include sedimentation and mineral and nutrient enrichment. Numerous stream segments do not support the designated uses for aquatic life and/or as a municipal and industrial water supply [1]. The causes of these impairments include surface erosion, urban nonpoint source pollution, and the effluent from municipal wastewater treatment plants (WWTP) [1]. Even so, at least the last two decades of water quality research in the Ozark Highlands have focused primarily on nutrient fluxes in surface runoff in response to animal manure application [2-5]. A need exists to evaluate the impact of treated wastewater on in-stream processes, focusing on how effluent discharges influence stream nutrient retention.
In the 2000s, numerous studies evaluated the effects of effluent discharges on nutrient dynamics within the stream channel [6-9]. Impacts of the effluent discharge in relatively small streams demonstrated the stream's inability to retain added phosphorous $(\mathrm{P})$ and nitrogen $(\mathrm{N})$; added nutrients were traveling kilometer-scale distances before being significantly retained. These streams provided short-term $\mathrm{N}$ storage through partial $\mathrm{N}$ cycling and nitrification of ammonium $\left(\mathrm{NH}_{4}-\mathrm{N}\right)$ to nitrate- $\mathrm{N}\left(\mathrm{NO}_{3}-\mathrm{N}\right)$. However, $\mathrm{NO}_{3}-\mathrm{N}$ often showed a net increase in transport downstream from the effluent discharge or traveled long distances before retention within the fluvial channel.

Nutrient studies evaluating impacts of WWTP effluent addition in other regions of the world have reported differing results. For example, a river near Berlin, Germany was studied with a two-reach approach that showed little to no effects on stream water chemistry from a mod- 
ern-day WWTP [10]. Gücker et al. [10] reported diminished rates of $\mathrm{P}$ and ammonium uptake, but increased nitrate uptake efficiency downstream of the WWTP. Gücker et al. [10] attributed the difference in their findings, as compared to previous studies, to the modern tertiary treatment of wastewater. Thus, it is clear that the effects of effluent discharges on nutrient dynamics and water chemistry vary with the treatment capacity of the WWTPs. Treese et al. [11] even suggested that clogging of the streambed may occur in effluent-dominated streams due to increased physical, chemical, and biological processes from elevated nutrients to render the stream unstable and result in a reduced capacity to recharge groundwater.

Most studies on the effects of effluent discharges on stream nutrient retention have focused on smaller streams, where the effluent discharge often has a profound effect on physio-chemical properties and makes up a large portion of discharge. Relatively few studies have focused on large rivers, when the effluent discharge is greatly diluted even during seasonal base-flow conditions. The Chattahoochee River, a large urban river near Atlanta, Georgia exhibited great variation in nutrient patterns downstream of multiple effluent discharges due to large fluctuations in river discharge and subsequent dilution of the effluents [12]. Thus, the dilution of effluent discharges plays a large role in the impact on water chemistry and nutrient transport downstream.

The objectives of this study were to evaluate the effects of WWTP effluent and river discharge on water quality and determine the retention efficiency of nutrients added in WWTP effluent in a 5th-order stream in the Ozark Highlands of northwest Arkansas. It was hypothesized that 1) there will be a no difference in water quality upstream and downstream of the WWTP effluent due to a large dilution effect, 2) dilution-corrected nutrient concentration differences will not be observed among downstream sample sites due to the relatively short study reach, 3) nutrient retention coefficients would not differ from zero indicating nutrient transport with no retention nor export was occurring, and 4) retention coefficients and net nutrient uptake lengths for $\mathrm{N}$ fractions would be unrelated, but those for $\mathrm{P}$ fractions would be related to certain water quality parameters, particularly turbidity.

\section{Methods}

\subsection{The Study Area}

The Ozark Highlands ecoregion covers parts of Kansas, Missouri, Oklahoma, and Arkansas [13] and is characterized by karst topography and high-gradient, riffle-pool, clear-flowing streams. Stream base flows throughout the dry summer months are maintained by springs and seeps.
The ecoregion is known for its rich aquatic diversity. Bedrock in the Ozark Highlands is typically limestone, dolomite, and chert. Historically, land cover was oak (Quercus spp.) - hickory (Carya spp.) forest with intermittent tallgrass prairie. Most of the tallgrass prairie has been converted to agriculture [14]. Approximately 20\% of the Ozark Highlands is used for pasture, $10 \%$ for cropland, and $70 \%$ is forestland [15].

The Ozark Highlands is also an area of concentrated poultry production [16]. Arkansas' broiler production is concentrated in the northwestern counties of Benton, Washington, Carroll, and Madison, all of which are located within the Ozark Highlands ecoregion. Poultry litter is rich in $\mathrm{N}, \mathrm{P}$, and potassium $(\mathrm{K})$ and is a cost-effective way of fertilizing soils [17]. Between 1.3 million and 1.8 million $\mathrm{Mg}$ of litter is generated in Arkansas annually. A large fraction of this litter is concentrated in northwest Arkansas [18]. This application of litter has resulted in high soil-test $P$ levels where pastures have been fertilized long-term [19] and numerous surface water quality issues throughout the region. Over the last 20 years, the northwest Arkansas portion of the Ozark Highlands has experienced a high rate of urbanization. From 2000 to 2007, the population within Washington and Benton counties increased by $28 \%$ from 311,121 to 397,399 [20]. The increasing population has placed greater demands on regional water resources, which relies on Beaver Lake within the White River Basin

The White River in northwest Arkansas is the largest tributary to Beaver Lake, and over 250,000 residents of northwest Arkansas use water from Beaver Lake as their source of drinking water. Three WWTPs discharge treated wastewater within the Beaver Lake-White River watershed. The Paul R. Noland WWTP in Fayetteville, $\mathrm{AR}$ is the largest contributor of treated wastewater to receiving waters within the watershed. The Paul R. Noland WWTP discharges effluent into the White River, which is classified as an impaired waterbody because of the lack of support for aquatic life due to excessive siltation and/or turbidity [1].

The White River is composed of three major branches: the West Fork, the Middle Fork, and the main fork, which is simply referred to as the White River (Figure 1). The three branches of the White River originate in the Boston Mountainss ecoregion and flow north to the Ozark Highlands ecoregion. The Middle Fork of the White River and the White River combine to form Lake Sequoyah, a small, shallow reservoir. The outflow of Lake Sequoyah combines with the West Fork of the White River and eventually flows into Beaver Lake.

This study was performed on a $6.1 \mathrm{~km}$ reach of the White River located between the confluence of the three 


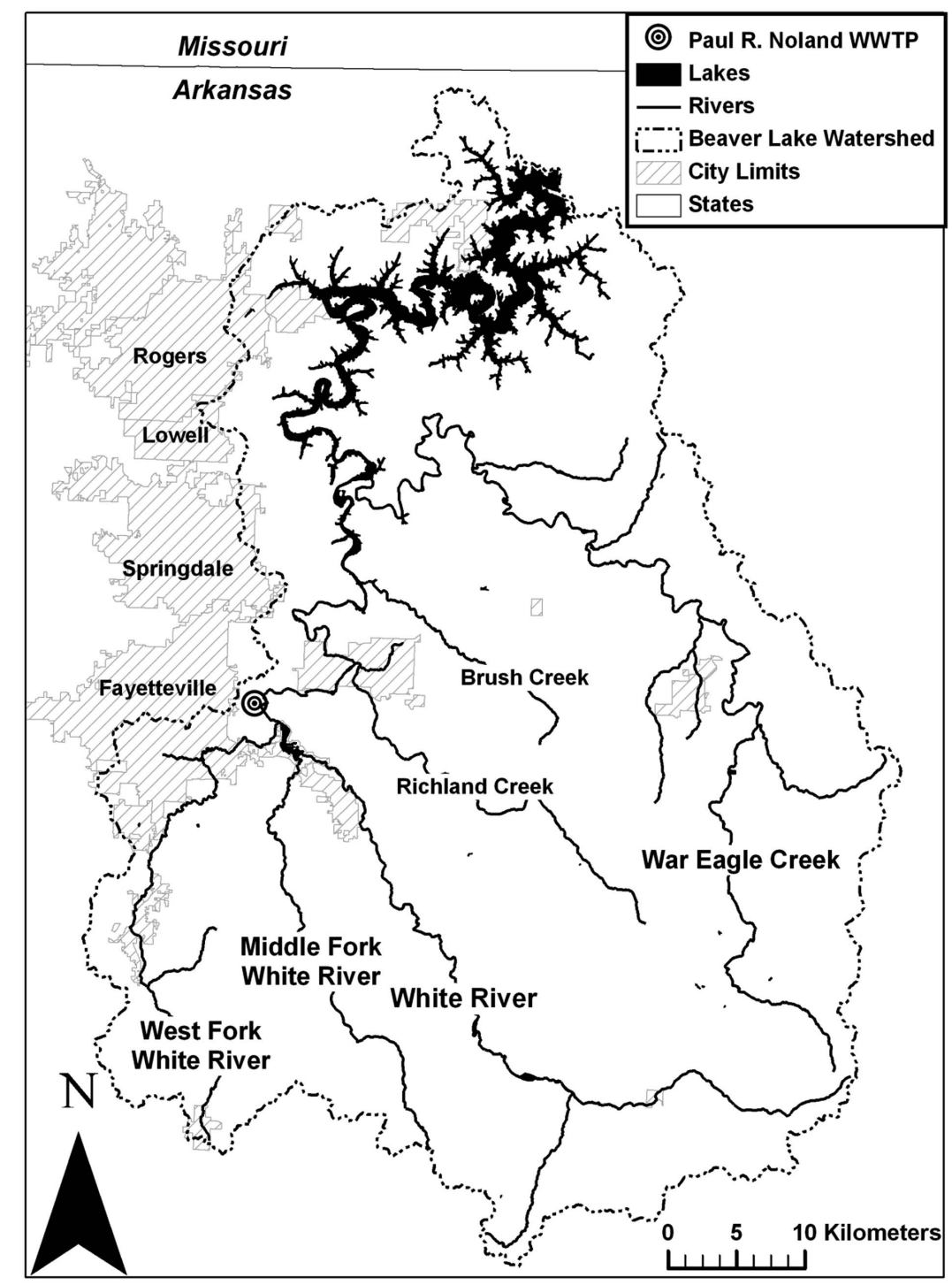

Figure 1. Map of the major rivers within the Beaver Lake Watershed in Northwest Arkansas. The Paul R. Noland municipal wastewater treatment plant (WWTP) discharges into the White River and was used as the nutrient input source for this study. The study reach stretches $2.2 \mathrm{~km}$ upstream of the WWTP discharge to $3.9 \mathrm{~km}$ downstream of the WWTP discharge.

forks of the White River and the headwaters of Beaver Lake. The entire reach examined in this study was in the Ozark Highlands. In 2004, the White River was designated to have an impaired ability to support aquatic life due to siltation and/or turbidity, where the source was likely from surface erosion. The causes of surface erosion were agricultural activities, unpaved road surfaces, and in-stream erosion mainly from unstable stream banks [21]. The White River was categorized as a high-priority for development of a total maximum daily load for the indicated pollutants [1].

Six sites were selected for sampling during the study, a United States Geological Survey (USGS) stream dis- charge monitoring station was located in the study reach, station 07084600 (Figure 2) at Wyman Bridge, just east of Fayetteville, AR. one upstream ( 2 km) of the Paul R. Noland WWTP just south of Wyman Bridge and five sites downstream were chosen at riffles, so that the water column would be mixed by the turbulence of the water moving over the shallow riffles. The only major water inflow between Sites 1 and 2 was the effluent discharge from the WWTP; there were no tributary inflows. The sites downstream were from $\sim 0.4$ to $\sim 4 \mathrm{~km}$ below the WWTP discharge into the White River.

For the 30-year period from 1971 to 2000, Fayetteville, AR experienced an average annual air temperature of 


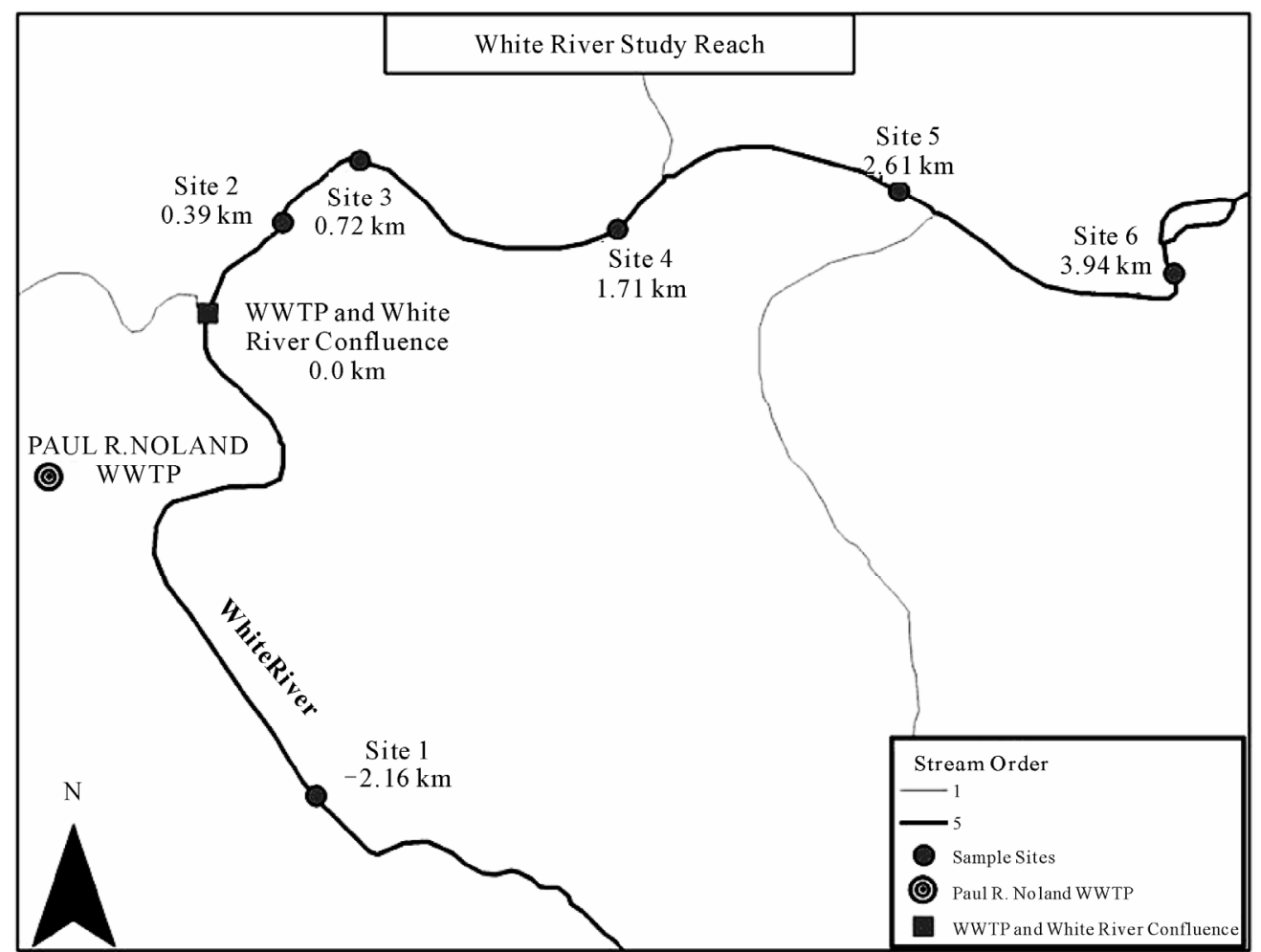

Figure 2. Map of the study reach with sampling sites and wastewater treatment plant (WWTP) discharge to the White river, northwest AR.

$14.2^{\circ} \mathrm{C}$ and average annual precipitation of $117 \mathrm{~cm} \mathrm{[22].}$ During the study period of 2006 and 2007, annual precipitation at the USGS station 07048600 totaled 86 and $72 \mathrm{~cm}, 26 \%$ and $38 \%$, respectively, below the 30 -year average [23]. The White River at Wyman Bridge has a total drainage area of $1036 \mathrm{~km}^{2}$ [24] and is $74 \%$ forested, $15 \%$ pasture, and $4 \%$ developed or urban.

\subsection{The Wastewater Treatment Plant}

At the time of this study, the Paul R. Noland WWTP was a Class IV, activated-sludge treatment plant with ultra-violet disinfection. The WWTP's National Pollution Discharge Elimination System (NPDES) permit allowed the WWTP to discharge a maximum of $27,710 \mathrm{~m}^{3} \cdot \mathrm{d}^{-1}$ into the White River, and the effluent quality was regulated by the Arkansas Department of Environmental Quality (ADEQ). Daily to hourly discharge flow data and effluent water quality records for days that sampling occurred were obtained directly from the WWTP (personal communication, Tim Luther, Operations Manager, CH2M HILL OMI). Effluent water quality data obtained included: daily averages of temperature, dissolved oxygen (DO), $\mathrm{pH}$, total suspended solids (TSS), soluble reactive phosphorous (SRP), total $\mathrm{P}$ (TP), and $\mathrm{NH}_{4}-\mathrm{N}$. Other forms of $\mathrm{N}$ (eg., $\mathrm{NO}_{3}-\mathrm{N}, \mathrm{NO}_{2}-\mathrm{N}$, and organic $\mathrm{N}$ ) were not routinely measured or reported for this effluent discharge, thus were unavailable to use and report in this study.

\subsection{Water Sample Collection, Processing, and Analyses}

Water sampling was conducted monthly, excluding December and February, for two consecutive years from January 2006 through 2007. Flow conditions in the White River below the 40 -year median flow of $10.5 \mathrm{~m}^{3} \cdot \mathrm{s}^{-1}$ were targeted as sampling dates, because higher flows presented some personnel safety considerations. At each of the six sampling sites, $\mathrm{pH}$, electrical conductivity, DO, and temperature were measured in-situ with a Thermo Orion 5 Star portable meter (Beverly, MA) at three points within the thalweg (i.e., left, middle, and right). A 1-L water sample was also collected at each of the three points within the thalweg at each sampling site. In the event of split flow resulting from channel morphological changes, both channels were measured for discharge (see below). If the secondary channel accounted for more than $20 \%$ of the total discharge, one or more of the three water samples were taken from its thalweg based on its estimated contribution to discharge.

A cross section was surveyed with 11 equally spaced survey points across the river channel for determining river discharge $(\mathrm{Q})$. The distance of the cross section was 
measured with a fiberglass measuring tape. Channel depth was determined with a Marsh McBirney measuring rod and flow velocity was measured electromagnetically with a Flo-Mate 2000 (Marsh McBirney, Fredrick, MA). River discharge was estimated using the product of the water velocity $\left(\mathrm{m} \cdot \mathrm{s}^{-1}\right)$ and cross-sectional area $\left(\mathrm{m}^{2}\right)$ for each area between survey points. The equal-interval discharges were then summed to estimate total river discharge at each sampling site.

Following collection, water samples were stored on ice in a dark cooler. Within 24 hrs after collection, sample bottles were shaken and a well-mixed, $40-\mathrm{mL}$ aliquot was removed and preserved to a $\mathrm{pH}$ of $\sim 2$ with two drops of concentrated $\mathrm{HCl}$ per $40 \mathrm{~mL}$ of solution for subsequent total organic carbon (TOC) and total $\mathrm{N}$ (TN) analyses. A $100-\mathrm{mL}$, well-mixed aliquot was then removed from the 1-L bottle and preserved to a $\mathrm{pH}$ of $\sim 2$ with two drops of $12 \mathrm{~N}$ sulfuric acid per $100 \mathrm{~mL}$ of solution for subsequent TP analysis. Turbidity was measured on a $20-\mathrm{mL}$ aliquot using a HACH $2100 \mathrm{~N}$ Turibidimeter (Loveland, CO) according to the SM 2130 B method [25]. Turbidity was reported in nephelometric turbidity units (NTU). The remaining portion of the initial 1-L sample was then vacuum-filtered through a $0.45-\mu \mathrm{m}$ filter. The filtered aliquot was used for subsequent SRP, nitrite $\left(\mathrm{NO}_{2}-\mathrm{N}\right), \mathrm{NO}_{3}-\mathrm{N}, \mathrm{NH}_{4}-\mathrm{N}$, and chloride (Cl-) analyses.

Chloride concentrations were determined according to the SM 4500-Cl- C mercuric-nitrate titration method [25]. Total organic carbon and TN were determined using a Shimadzu TOC-VCSH TOC analyzer with an added THM-1 TN measuring unit (Shimadzu, Kyoto, Japan) using the SM $5310 \mathrm{~B}$ [25] and ASTM D 5176-91 methods [26], respectively. Determinations of $\mathrm{NO}_{3}-\mathrm{N}, \mathrm{NO}_{2}-\mathrm{N}$, $\mathrm{NH}_{4}-\mathrm{N}, \mathrm{SRP}$, and TP were conducted using a HACH DR 4000 (HACH, Loveland, CO.) spectrophotometer. Nitrate was reduced to $\mathrm{NO}_{2}-\mathrm{N}$ using the $\mathrm{SM} 4500-\mathrm{NO}_{3}-\mathrm{E}$ cadmium-copper reduction method [25]. The resulting reduced-sample was colormetrically analyzed for determination of the $\mathrm{NO}_{2}-\mathrm{N}$ concentration. The difference between the reduced-sample $\mathrm{NO}_{2}-\mathrm{N}$ concentration and the previously determined $\mathrm{NO}_{2}-\mathrm{N}$ concentration was determined to be the $\mathrm{NO}_{3}-\mathrm{N}$ concentration [25]. Ammonium was determined by the HACH Nessler method 8038 [27]. Nitrite was determined by the HACH Diazotization method 8507 [27]. Soluble-reactive P was determined by the HACH ascorbic acid method 8048 [27]. Preserved TP water samples were digested according to the persulfate digestion method (SM 4500-P B) and determined colormetrically by the $\mathrm{HACH}$ ascorbic acid method [27]. All analyses were conducted before recommended holding times had expired [25].

\subsection{Nutrient Retention, Export, or Net Uptake}

Nutrients added to an aquatic system are retained in, transported through, or exported from the system (i.e., added to the water column) [28]. The fraction of nutrients retained within the study reach (i.e., the retention coefficient (RC)) was calculated using the nutrient loads from Sites 2 (S2) and 6 (S6) with Equation 1:

where $\mathrm{N}$ was the mean measured nutrient concentration $\left(\mathrm{mg} \cdot \mathrm{L}^{-1}\right)$ and $\mathrm{Q}$ was the measured river discharge $\left(\mathrm{m}^{3} \cdot \mathrm{s}^{-1}\right)$ for the respective Site 2 (S2) or 6 (S6). Since $\mathrm{NO}_{2}-\mathrm{N}$ made up such a small percentage of the inorganic $\mathrm{N}$ fraction in the water column, the combined $\mathrm{NO}_{2}-\mathrm{N}+\mathrm{NO}_{3}-\mathrm{N}$ concentration was used in this analysis. Calculating nutrient export or retention in this way is a general approach that examines only reach-level inputs and outputs, which rely on measured Q at the sites. Streams and rivers in the Ozark Highlands often have relatively large subsurface Q flowing through the gravel alluvium within the fluvial channel.

The WWTP effluent was used as the nutrient source for determining net nutrient uptake length $\left(\mathrm{S}_{\mathrm{NET}}\right)$. The $\mathrm{S}_{\mathrm{NET}}$ approach evaluates longitudinal changes in nutrient concentration throughout the entire study reach, where $S_{\text {NET }}$ is a more quantitative approach to examining nutrient dynamics within a study reach than just examining nutrient inputs and outputs. The mean concentration (based on three sub-samples) at each sampling site was corrected for downstream of the effluent discharge (Site 2) using Equation (2):

$$
\mathrm{N}_{\mathrm{D}}=\left(\mathrm{N}_{\mathrm{x}} * \mathrm{Cl}_{0}\right) / \mathrm{Cl}_{\mathrm{x}}
$$

where $\mathrm{N}_{\mathrm{D}}$ was the dilution-corrected concentration $\left(\mathrm{mg} \cdot \mathrm{L}^{-1}\right)$ for the nutrient of choice, $\mathrm{N}_{\mathrm{X}}$ was the mean nutrient concentration $\left(\mathrm{mg} \cdot \mathrm{L}^{-1}\right)$ at sample site $\mathrm{x}, \mathrm{Cl}_{0}$ was the mean chloride concentration $\left(\mathrm{mg} \cdot \mathrm{L}^{-1}\right)$ from Site 2 (i.e., the immediate downstream sample site of the WWTP), and $\mathrm{Cl}_{\mathrm{X}}$ was the mean chloride concentration $\left(\mathrm{mg} \cdot \mathrm{L}^{-1}\right)$ at sampling site $\mathrm{x}$. The proportion of nutrient remaining in the water column was then calculated using Equation (3):

$$
\mathrm{P}_{\mathrm{NX}}=\mathrm{N}_{\mathrm{DX}} / \mathrm{N}_{\mathrm{D} 0}
$$

where $\mathrm{P}$ was the proportion of the dilution-corrected nutrient $(\mathrm{N})$ concentration remaining in the water column at site (X). The proportion remaining in the water column (P) was natural-log transformed, and the slope of the linear relationship between the natural-log of the proportion remaining in the water column and the distance from

$$
\mathrm{RC}=\left[\left(\mathrm{N}_{\mathrm{S} 2} * \mathrm{Q}_{\mathrm{S} 2}\right)-\left(\mathrm{N}_{\mathrm{S} 6} * \mathrm{Q}_{\mathrm{S} 6}\right)\right] /\left(\mathrm{N}_{\mathrm{S} 2} * \mathrm{Q}_{\mathrm{S} 2}\right)
$$


the WWTP discharge represented K. When K (i.e., the slope) was significant (i.e., different from 0 ) at the $\mathrm{p}<$ 0.1 , then $\mathrm{S}_{\mathrm{NET}}$ was calculated with Equation (4):

$$
\mathrm{S}_{\mathrm{NET}}=-1 / \mathrm{K}
$$

Net nutrient uptake length $\left(\mathrm{S}_{\mathrm{NET}}\right)$ was expressed in $\mathrm{km}$ and was calculated for SRP, $\mathrm{NO}_{3}-\mathrm{N}$, and $\mathrm{NH}_{4}-\mathrm{N}$ for each sampling date. Negative $\mathrm{S}_{\mathrm{NET}}$ values represented net release of the nutrient through the study reach, while positive distances demonstrate net retention with long distance suggesting less efficient retention than shorter distances (Newbold et al., 1981). An alpha value of 0.1 was used to judge significance due to the large scale (i.e., $5^{\text {th }}$-order stream) of the White River [see also 12].

The net mass transfer coefficient $\left(\mathrm{V}_{\mathrm{F}-\mathrm{NET}}\right)$ was calculated using $\mathrm{S}_{\mathrm{NET}}$, $\mathrm{Q}$, and the average wetted width of the river (W) using Equation (5):

$$
\mathrm{V}_{\mathrm{F}-\mathrm{NET}}=\mathrm{Q} /\left(\mathrm{S}_{\mathrm{NET}} * \mathrm{~W}\right)
$$

and was expressed in $\mathrm{m} \mathrm{s}^{-1}$. The $\mathrm{V}_{\mathrm{F}-\mathrm{NET}}$ is the velocity at which nutrients travel from the water column to the stream substrate, and removes some hydrologic effects for across site and date comparisons.

Net nutrient uptake rate $\left(\mathrm{U}_{\mathrm{NET}}\right)$ was then calculated by Equation 6:

$$
\mathrm{U}_{\mathrm{NET}}=\mathrm{V}_{\mathrm{F}-\mathrm{NET}} * \mathrm{C}_{0}
$$

and was expressed in $\mathrm{mg} \mathrm{m}^{2} \mathrm{~s}^{-1}$. This parameter considers changes in concentrations downstream from the effluent discharge to estimate net uptake rates.

\subsection{Statistical Analyses}

River discharge was graphically examined initially and, due to large temporal variations, was divided into three qualitative categories [i.e., Low $\left(<2 \mathrm{~m}^{3} \cdot \mathrm{s}^{-1}\right)$, Medium (2 $\left.6 \mathrm{~m}^{3} \cdot \mathrm{s}^{-1}\right)$, and High $\left.\left(>6 \mathrm{~m}^{3} \cdot \mathrm{s}^{-1}\right)\right]$ based on the frequency of sampling days with similar discharge rates (Figure 3).

Water quality parameters (i.e., $\mathrm{TN}, \mathrm{NO}_{3}-\mathrm{N}, \mathrm{NO}_{2}-\mathrm{N}$, $\mathrm{NH}_{4}$ - N, TP, SRP, turbidity, TOC, $\mathrm{Cl}, \mathrm{pH}$, conductivity, temperature, and DO) upstream of the municipal WWTP discharge (Site 1) were compared to those at the first site immediately downstream (Site 2) to evaluate the immediate effect of WWTP effluent on water quality. This was accomplished by conducting a two-factor analysis of variance (ANOVA) using SAS (version 9.1, SAS Institute, Inc., Cary, NC) to evaluate the effect of site (upstream and downstream) and flow regime (i.e., low, medium, and high) on water quality parameters. In addition, paired t-tests were performed separately within each flow regime comparing parameters upstream and downstream to further evaluate the effect of the WWTP effluent discharge on river water quality (Minitab 13.31, Minitab
Inc., State College, PA).

On dates in which $\mathrm{S}_{\mathrm{NET}}$ was significant, simple correlation analyses using Minitab were performed to evaluate the relationship between the $\mathrm{S}_{\mathrm{NET}}$ of individual nutrients and other water quality parameters. An alpha level of 0.1 was decided a priori to use to judge the significance of $S_{\text {NET }}$ values due to the expected large spatial variability with the measured parameters. An alpha level of 0.05 was used to judge significance for all correlations conducted. The parameters that were analyzed included: Site 2 nutrient concentrations ( $\mathrm{SRP}, \mathrm{NO}_{3}-\mathrm{N}, \mathrm{NH}_{4}-\mathrm{N}, \mathrm{TP}$, and TN), TOC, turbidity, conductivity, temperature, $\mathrm{pH}$, DO, and the mean Q averaged across all six sites. Site 2 was chosen because the water quality parameters downstream would show how the effluent discharge might influence nutrient dynamics. An average Q was calculated and used instead of Q measured at Site 2 because of the fluctuations from site to site due to interflow within the gravel streambed.

\section{Results and Discussion}

\subsection{River and WWTP Discharge}

White River discharge varied over the 20 sampling months from $0.1 \mathrm{~m}^{3} \cdot \mathrm{s}^{-1}$ in August 2006 to $14.3 \mathrm{~m}^{3} \cdot \mathrm{s}^{-1}$ in January 2007 in response to local precipitation (Figure 3). Average discharge was $4.2 \mathrm{~m}^{3} \cdot \mathrm{s}^{-1}$ on days the river was sampled. Based on the $<2,2$ to 6 , and $>6 \mathrm{~m}^{3} \cdot \mathrm{s}^{-1}$ discharge thresholds, there were a total of 7, 7, and 6 sampling dates that represented the low, medium and high flow categories, respectively (Figure 3). The 42-year (1964 to 2006) average river discharge for the study reach was $15.3 \mathrm{~m}^{3} \mathrm{~s}^{-1}$ and included storm-flow as well as base-flow discharge [29]. White River discharge was below the 42-year average on all sample dates in this study. Thus, the flow-regime categories that were assigned for this study do not represent the total variation in White River discharge.

The WWTP discharge ranged from $0.1 \mathrm{~m}^{3} \cdot \mathrm{s}^{-1}$ in August 2006 and September 2007 to $0.6 \mathrm{~m}^{3} \cdot \mathrm{s}^{-1}$ in March and October 2007 (Figure 3), averaging $0.3 \mathrm{~m}^{3} \cdot \mathrm{s}^{-1}$ over the 20 sampling months. Effluent discharge was less variable compared to river discharge on days sampled. The WWTP discharge contribution to river discharge at Site 2 ranged from 2 to almost $100 \%$ of streamflow, averageing $19 \%$ of the total river discharge on the days sampled. During August 2006, the low-flow conditions coupled with gravel streambed material could explain the reported WWTP discharge being larger than the measured river discharge as flow through the gravel alluvium was likely occurring. The variation in the degree to which dilution occurred immediately after the WWTP effluent discharge was part of the reason that river discharge was 


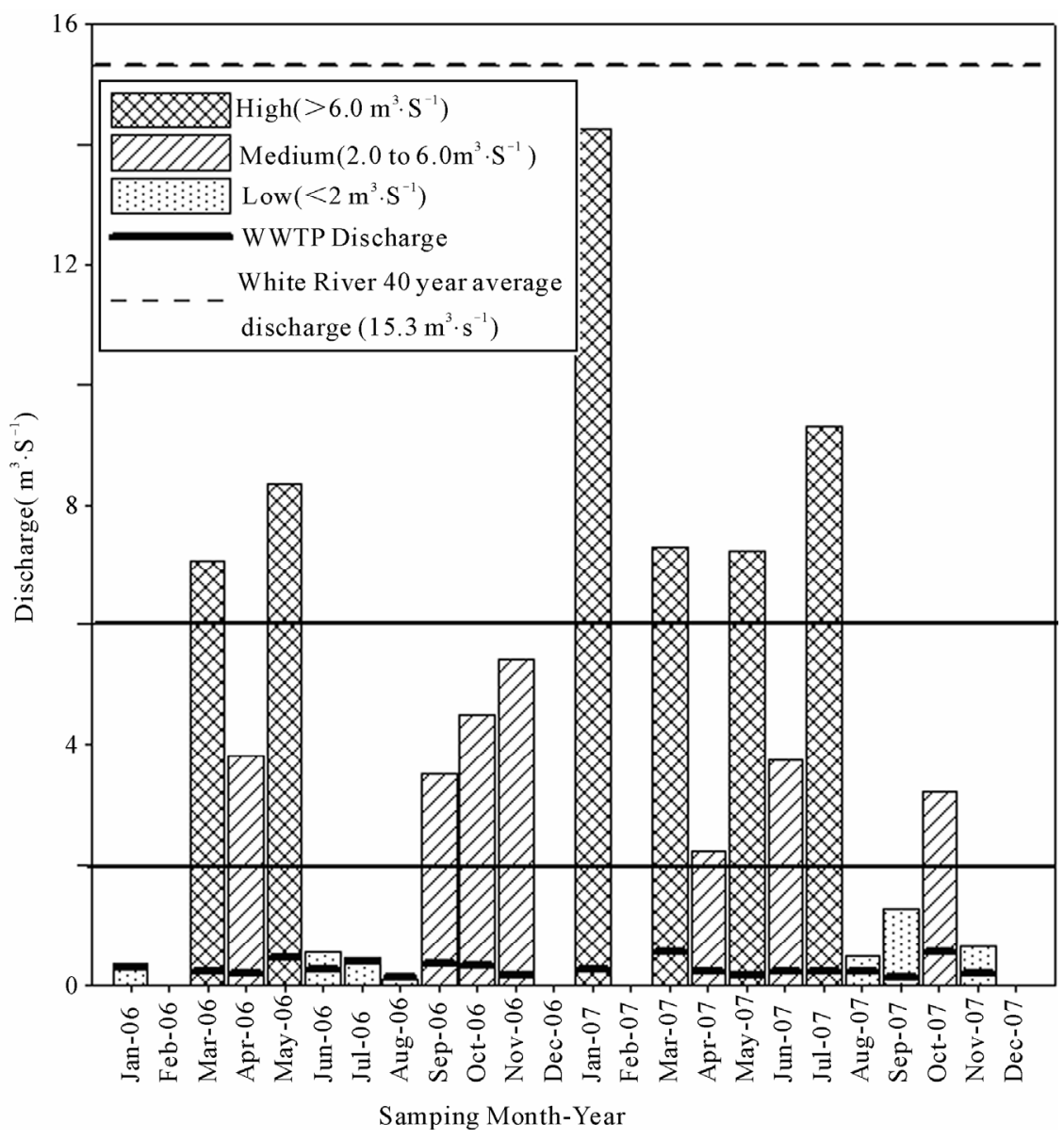

Figure 3. White River discharge throughout a 20-month sampling period from January 2006 to December 2007. Also plotted are the wastewater treatment plant (WWTP) discharge into the White river and the 40-yr average White River discharge. river discharge was quantitatively divided into three flow regimes (Low, Medium, and High). Horizontal lines at 2.0 and $6.0 \mathrm{~m}^{3}$ $\mathrm{s}^{-1}$ indicate the thresholds separating the three flow regimes.

qualitatively categorized for purposes of this study.

\subsection{Water Quality Upstream of the WWTP Discharge}

Stream water quality was measured upstream of the WWTP on all 20 sampling dates (Table 1). Turbidity varied greatly across sampling dates ranging from 1.9 in August 2006 to 45.2 NTU in March 2006. There was a total maximum daily load (TMDL) present for turbidity that was set by the ADEQ as required for impaired waterbodies. Since no stream load data could be assessed for turbidity (i.e., there is no concentration associated with NTU because it is an optical measurement), total suspended solids (TSS) was used as a surrogate to turbidity to develop the TMDL. A target base-flow TSS concentration of $11 \mathrm{mg} \cdot \mathrm{L}^{-1}$ was reported to correspond with a turbidity level of 10 NTU, while a storm-flow TSS target of $12 \mathrm{mg} \cdot \mathrm{L}^{-1}$ corresponded with a turbidity level of 17 NTU [30]. Turbidity at Site 1 exceeded the base-flow TMDL on $50 \%$ of the sample dates. All forms of $\mathrm{N}$ measured (i.e., $\mathrm{NO}_{3}-\mathrm{N}, \mathrm{NO}_{2}-\mathrm{N}, \mathrm{NH}_{4}-\mathrm{N}$, and $\mathrm{TN}$ ) had maximum concentrations $<1.0 \mathrm{mg} \cdot \mathrm{L}^{-1}$ during the sampling dates, and maximum SRP and TP concentrations were $\leq 0.05 \mathrm{mg} \cdot \mathrm{L}^{-1}$ (Table 1).

\subsection{WWTP Effluent Characteristics}

As was expected, some effluent characteristics varied seasonally, while others did not. Effluent temperature varied seasonally from a low of $13.0^{\circ} \mathrm{C}$ in March 2007 to a high of $27.2^{\circ} \mathrm{C}$ in August 2007 and averaged $21.1^{\circ} \mathrm{C}$ across the study period. Similarly, effluent DO concentration displayed a seasonal pattern varying from an average of $8.3 \mathrm{mg} \cdot \mathrm{L}^{-1}$ in July and August to $13.2 \mathrm{mg} \cdot \mathrm{L}^{-1}$ in March and averaged $9.1 \mathrm{mg} \cdot \mathrm{L}^{-1}$ across the study period. Since oxygen solubility is known to be inversely related to water temperature, this observed variation was expected. Effluent TSS concentrations also varied, but not seasonally, ranging from a low of $0.5 \mathrm{mg} \cdot \mathrm{L}^{-1}$ in Septem- 
ber 2007 to a high of $8.5 \mathrm{mg} \cdot \mathrm{L}^{-1}$ in January 2007 and averaging $2.7 \mathrm{mg} \cdot \mathrm{L}^{-1}$ across the study period. Effluent pH varied between pH 7 in January 2006 and 7.9 in September 2007.

Effluent SRP and TP concentrations were both $<0.4$ $\mathrm{mg} \cdot \mathrm{L}^{-1}$, except for in April, May, and June 2006. Total P and SRP were greatest in the effluent during May 2006, 1.9 and $1.4 \mathrm{mg} \cdot \mathrm{L}^{-1}$, respectively. These concentrations were much greater than any observed $\mathrm{P}$ concentrations from the White River. Effluent ammonium concentrations were $<0.5 \mathrm{mg} \cdot \mathrm{L}^{-1}$ on all sampling dates except in the months of March and April 2006 and in April 2007. April 2007 had the greatest observed $\mathrm{NH}_{4}$-N concentration $\left(1.8 \mathrm{mg} \cdot \mathrm{L}^{-1}\right)$. The exact reason for the three months of elevated SRP, TP, and $\mathrm{NH}_{4}-\mathrm{N}$ concentrations in the effluent discharge is unknown.

When wastewater effluent $\mathrm{NH}_{4}-\mathrm{N}, \mathrm{SRP}$, and TP concentrations were compared with river concentrations at Site 1 and 2, effluent nutrient concentrations were often related to that observed downstream. Site 2 river SRP $(r=0.67, p<0.01)$ and $\mathrm{NH}_{4}-\mathrm{N}(r=0.53, p<0.05)$ concentrations were significantly positively correlated with the WWTP effluent concentrations. These correlations indicate that the WWTP effluent was a major factor influencing downstream dissolved $\mathrm{P}$ and $\mathrm{NH}_{4}-\mathrm{N}$ concentrations in the White River.

\subsection{Upstream-Downstream Comparison}

With the exception of $\mathrm{NH}_{4}-\mathrm{N}, \mathrm{pH}$, and temperature, all other water quality parameters measured in this study were affected by site (i.e., upstream or downstream), flow regime (i.e., low, medium, or high), or both (Table 2). Based on the two-factor ANOVA, measured $\mathrm{Cl}^{-}, \mathrm{TN}$, $\mathrm{TP}$, and $\mathrm{NO}_{3}-\mathrm{N}$ concentrations were greater downstream than upstream of the WWTP discharge during low-flow $(p<0.01)$, but did not differ between sites during medium- or high-flow conditions (Figure 4). Measured $\mathrm{Cl}^{-}, \mathrm{TN}, \mathrm{TP}$, and $\mathrm{NO}_{3}-\mathrm{N}$ concentrations at Site 2 ranged from 14 to $76 \mathrm{mg} \mathrm{Cl}{ }^{-} \cdot \mathrm{L}^{-1}, 0.9$ to $10.6 \mathrm{mg} \mathrm{TN} \cdot \mathrm{L}^{-1}$, 0.04 to $0.16 \mathrm{mg} \mathrm{TP} \cdot \mathrm{L}^{-1}$, and 0.6 to $11.7 \mathrm{mg} \mathrm{NO}{ }_{3}-\mathrm{N} \cdot \mathrm{L}^{-1}$ across sample dates during low-flow conditions. These same sites ranged from 5 to $14 \mathrm{mg} \mathrm{Cl} \cdot \mathrm{L}^{-1}, 0.3$ to $2.7 \mathrm{mg}$ $\mathrm{TN} \cdot \mathrm{L}^{-1}, 0.01$ to $0.13 \mathrm{mg} \mathrm{TP} \cdot \mathrm{L}^{-1}$, and 0.2 to $2.4 \mathrm{mg}$ $\mathrm{NO}_{3}-\mathrm{N} \cdot \mathrm{L}^{-1}$ across sample dates during medium- and high-flow conditions. During low-flow, the relatively high concentrations of $\mathrm{Cl}^{-}, \mathrm{TN}, \mathrm{TP}$, and $\mathrm{NO}_{3}-\mathrm{N}$ in the WWTP effluent affected river water chemistry due to less dilution in the river when compared to higher base flows (i.e., medium and high flows in this study). This supports the assumption that the degree of dilution, based on river discharge, plays an important role in the nutrient enrichment of the White River. Based on paired t-tests that were conducted separately by flow regime, the concentrations of $\mathrm{Cl}^{-}$and TP were always greater $(p<0.05)$ downstream from the WWTP effluent discharge than upstream, further indicating the significant impact that the WWTP effluent discharge has on stream water chemistry. Nitrate accounted for $91 \%$ of TN across both sites and all sample dates; thus results for nitrate and TN were similar. Nitrogen and $\mathrm{Cl}^{-}$concentrations have been shown to be elevated below a WWTP discharge in other point-source-receiving streams in the Ozark Highlands $[6,7,32]$, therefore, it was not surprising that the WWTP effluent affected downstream stream concentrations most when diluting flows (i.e., high discharge flow rates) were not present in the White River.

Nitrite, SRP, TOC, and conductivity were greater $(p<$ $0.04)$ downstream than upstream when averaged across all flow regimes (Table 2). The mean downstream $\mathrm{NO}_{2}-\mathrm{N}$ concentration was more than double that of the upstream concentration (Table 3). Nitrite is an intermediate form of $\mathrm{N}$ during nitrification and is not stable in the environment [33]. Soluble reactive $\mathrm{P}$ is biologically important because it is often the limiting nutrient for primary production in White River tributaries [34], but concentrations were generally low $\left(<0.1 \mathrm{mg} \mathrm{SRP} \mathrm{L}^{-1}\right)$ on all sample dates throughout the study. The mean river SRP concentration in the White River was four times greater downstream than upstream of the WWTP when averaged across flow regimes. The TOC concentration was $35 \%$ greater downstream from the WWTP effluent discharge compared to upstream (Table 3). Carbon added from the WWTP effluent provides more substrate for microorganisms in the river which can lead to more heterotrophic production, which could influence microbial processes and reach-level retention capacity. Stream conductivity was always greater, on average $62 \%$ greater, downstream than upstream of the WWTP effluent discharge (Table 3) because of the added solutes in the effluent.

Based on the ANOVA, turbidity and DO did not differ between Site 1 and 2 (Tables 2 and 3). However, based on a paired t-test within each flow regime, DO was greater downstream than upstream of the WWTP effluent discharge during low flow and was similar when flow exceeded $2 \mathrm{~m}^{3} \cdot \mathrm{s}^{-1}$. Conductivity, TOC, DO, and turbidity varied among flow regimes $(p<0.015)$ when averaged across sites (Table 2). Both TOC and conductivity were greatest during low-flow conditions and did not differ between medium and high-flow conditions (Table 4). Conductivity during medium and high-flow conditions was less than one half that observed during low-flow 
conditions (as defined in this study). Total organic carbon also experienced a similar decrease as that of conductivity as the flow regime increased. Dilution of the WWTP effluent was likely the mechanism responsible for these changes when discharge exceeded $2 \mathrm{~m}^{3} \cdot \mathrm{s}^{-1}$.

Dissolved oxygen varied among all three flow regimes and increased as flow regime increased (Table 4). The increased mixing and aeration from more turbulent flow during increasingly greater discharge rates were likely responsible for increasing DO concentrations. Though water temperature was statistically unaffected by either site or flow regime (Table 2), water temperature numerically decreased from the low- to the high-flow regime, while the DO concentration significantly increased (Table 4), which was expected.

Similar to DO, turbidity was also greater during highthan low-flow conditions, but turbidity during mediumflow was similar to that during both low- and high-flow conditions (Table 4). The amount of suspended sediment in the water column is typically directly proportional to the water velocity, thus it was not surprising that turbidity was greatest during high-flow conditions. However, the relationship between exposure to and actual biological impairment from suspended sediment, as characterizes numerous streams in the Ozark Highlands, is poorly understood [35].

Neither site nor flow regime affected $(p>0.05)$ $\mathrm{NH}_{4}-\mathrm{N}$ concentrations, water temperature, or $\mathrm{pH}$ based on the ANOVA (Table 2). Averaged across sites and flow regimes, mean ammonium concentration was 0.1 $\mathrm{mg} \cdot \mathrm{L}^{-1}$, mean $\mathrm{pH}$ was 7.3 , and mean water temperature was $18.6^{\circ} \mathrm{C}$. However, based on a paired t-test within each flow regime, water temperature was slightly greater downstream than upstream of the WWTP effluent discharge when flows exceeded $6 \mathrm{~m}^{3} \cdot \mathrm{s}^{-1}$.

\subsection{Water Quality Downstream of the WWTP Discharge}

White River water quality measured at the five sites downstream of the WWTP effluent discharge varied widely. Turbidity ranged from 5 to 50 NTU across all downstream sample sites and dates during this study (Table 5). The average turbidity for Sites 2 through 6 was above the TMDL NTU limit on $45 \%$ of the sampling dates. The WWTP's point-source-pollution effect was apparent based on increased nutrient concentrations, conductivity, and $\mathrm{Cl}^{-}$. The mean $\mathrm{NO}_{3}-\mathrm{N}$ concentration at Sites 2 through 6 averaged across sample dates was $3.2 \mathrm{mg} \cdot \mathrm{L}^{-1}$, which was more than three times the mean $\mathrm{NO}_{3}-\mathrm{N}$ concentration at Site 1 upstream of the WWTP discharge (Table 1). River TP averaged $0.10 \mathrm{mg} \mathrm{TP} \mathrm{L}^{-1}$ across downstream sample locations and dates, but exceeded the EPA-recommended reference P concentration for Ecoregion XI of $0.01 \mathrm{mg} \cdot \mathrm{L}^{-1}$ [31] with a maximum observed concentration $0.32 \mathrm{mg}$ TP. $\mathrm{L}^{-1}$. Chloride concentrations ranged from 5 to $77 \mathrm{mg} \cdot \mathrm{L}^{-1}$ and averaged 30 $\mathrm{mg} \cdot \mathrm{L}^{-1}$. The mean chloride concentration for Sites 2 through 6 was more than five times greater than Site 1 upstream of the WWTP (Table 1). Mean conductivity for Sites 2 through $6\left(330 \mu \mathrm{S} \cdot \mathrm{cm}^{-1}\right)$ was two times great-
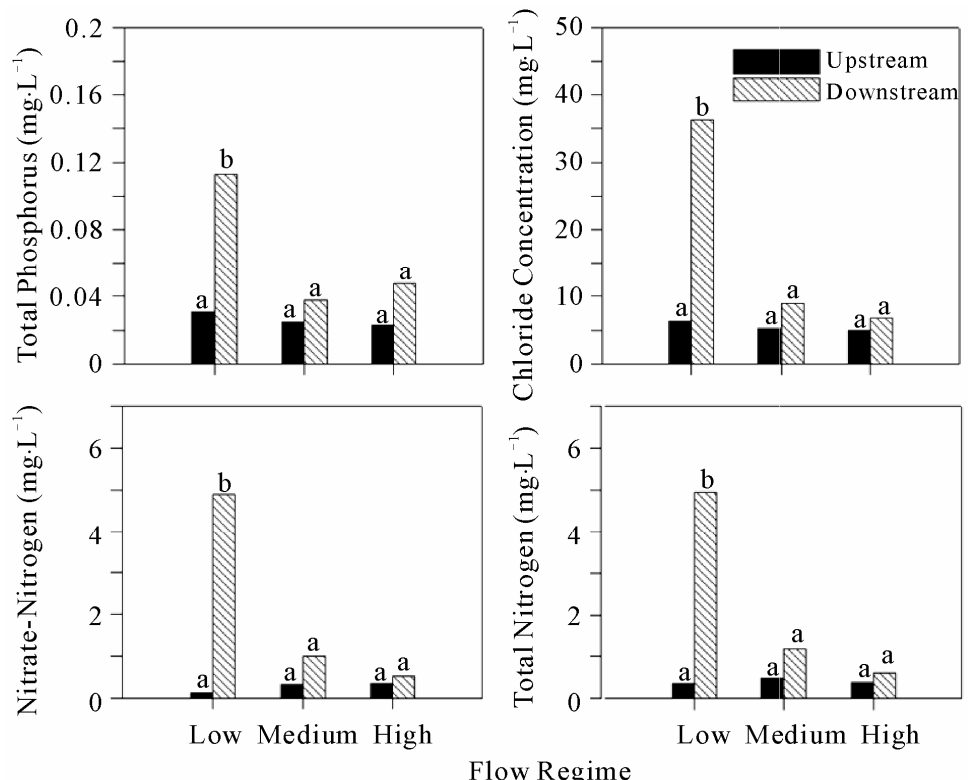

Figure 4. Flow regime (i.e., Low, Medium, and High) and site location (i.e., upstream and downstream of the wastewater treatment plant) effects on water quality parameters in the White River, Fayetteville, AR. Different letters above bars for the same parameter are different at the 0.05 level. 
Table 1. Summary of water quality characteristics averaged across all flow regimes in the White river upstream (i.e., Site 1) of the Paul R. Noland Wastewater Treatment Plant in Fayetteville, AR.

\begin{tabular}{cccc}
\hline Water quality parameter & Minimum & Maximum & Average \\
\hline Nitrate $\left(\mathrm{mg} \cdot \mathrm{L}^{-1}\right)$ & $<0.01$ & 0.87 & 0.26 \\
Nitrite $\left(\mathrm{mg} \cdot \mathrm{L}^{-1}\right)$ & $<0.01$ & 0.01 & 0.01 \\
Ammonium $\left(\mathrm{mg} \cdot \mathrm{L}^{-1}\right)$ & 0.01 & 0.31 & 0.07 \\
Total nitrogen $\left(\mathrm{mg} \cdot \mathrm{L}^{-1}\right)$ & 0.20 & 0.78 & 0.40 \\
Soluble reactive phosphorus $\left(\mathrm{mg} \cdot \mathrm{L}^{-1}\right)$ & $<0.01$ & 0.01 & $<0.01$ \\
Total phosphorus $\left(\mathrm{mg} \cdot \mathrm{L}^{-1}\right)$ & $<0.01$ & 0.05 & 0.03 \\
Turbidity $\left(\mathrm{NTU} \mathrm{U}^{*}\right)$ & 1.9 & 45.2 & 13.1 \\
Total organic carbon $\left(\mathrm{mg} \cdot \mathrm{L}^{-1}\right)$ & 0.8 & 4.1 & 2.3 \\
Chloride $\left(\mathrm{mg} \cdot \mathrm{L}^{-1}\right)$ & 3.8 & 10.2 & 5.6 \\
Dissolved oxygen $\left(\mathrm{mg} \cdot \mathrm{L}^{-1}\right)$ & 4.1 & 11.6 & 8.0 \\
pH & 6.6 & 7.7 & 7.3 \\
Conductivity $\left(\mu \mathrm{S} \cdot \mathrm{cm}^{-1}\right)$ & 86 & 440 & 163 \\
Temperature $\left({ }^{\circ} \mathrm{C}\right)$ & 5.7 & 28.8 & 18.4 \\
\hline
\end{tabular}

* Nephalometric turbidity units (NTU)

Table 2. Analysis of variance summary of the effects of site, flow regime, and their interaction on water quality parameters measured upstream and downstream of the wastewater treatment plant effluent discharge into the White river in Fayetteville, AR.

\begin{tabular}{cccc}
\hline \multirow{2}{*}{ Water quality parameter } & \multicolumn{3}{c}{ Source of variation } \\
\cline { 2 - 4 } & Site & Flow regime & Site x flow regime \\
\hline Nitrate & & $p$ & 0.004 \\
Nitrite & 0.003 & 0.011 & 0.382 \\
Ammonium & 0.015 & 0.347 & 0.863 \\
Total nitrogen & 0.424 & 0.217 & 0.003 \\
Soluble reactive phosphorus & 0.002 & 0.004 & 0.150 \\
Total phosphorus & 0.003 & 0.156 & 0.009 \\
Turbidity & $<0.001$ & 0.002 & 0.999 \\
Total organic carbon & 0.969 & 0.015 & 0.072 \\
Chloride & 0.027 & $<0.001$ & 0.001 \\
Dissolved oxygen & $<0.001$ & $<0.001$ & 0.717 \\
pH & 0.898 & $<0.001$ & 0.940 \\
Conductivity & 0.242 & 0.153 & 0.107 \\
Temperature & 0.040 & $<0.001$ & 0.992 \\
\hline
\end{tabular}

Table 3. Summary of the effect of site averaged across flow regime, on water quality parameters measured upstream and downstream of the wastewater treatment plant discharge into the White river in Fayetteville, AR. Mean values are reported with standard errors in parentheses.

\begin{tabular}{|c|c|c|c|}
\hline Water quality parameter & Upstream & Downstream & $\operatorname{LSD}_{0.05}{ }^{\dagger}$ \\
\hline Nitrate $\left(\mathrm{mg} \cdot \mathrm{L}^{-1}\right)$ & $0.3(<0.1)$ & $2.2(0.7)^{*}$ & $1.2^{\dagger \dagger}$ \\
\hline Nitrite $\left(\mathrm{mg} \cdot \mathrm{L}^{-1}\right)$ & $<0.01(<0.01)$ & $0.02(<0.01)^{*}$ & 0.01 \\
\hline Ammonium $\left(\mathrm{mg} \cdot \mathrm{L}^{-1}\right)$ & $0.07(0.01)$ & $0.09(0.02)$ & - \\
\hline Total nitrogen $\left(\mathrm{mg} \cdot \mathrm{L}^{-1}\right)$ & $0.4(<0.1)$ & $2.3(0.7)^{*}$ & $1.1^{\dagger \dagger}$ \\
\hline Soluble reactive phosphorus $\left(\mathrm{mg} \cdot \mathrm{L}^{-1}\right)$ & $<0.01(<0.01)$ & $0.04(0.01)^{*}$ & 0.02 \\
\hline Total phosphorus $\left(\mathrm{mg} \cdot \mathrm{L}^{-1}\right)$ & $0.03(<0.01)$ & $0.07(0.01)^{*}$ & $0.02^{\dagger \dagger}$ \\
\hline Turbidity (NTU) & $13.0(2.2)$ & $13.1(2.2)$ & - \\
\hline Total organic carbon $\left(\mathrm{mg} \cdot \mathrm{L}^{-1}\right)$ & $2.3(0.2)$ & $3.1(0.4)^{*}$ & 0.66 \\
\hline Chloride $\left(\mathrm{mg} \cdot \mathrm{L}^{-1}\right)$ & $5.6(0.3)$ & $17.9(4.3)^{*}$ & $6.5^{\dagger \dagger}$ \\
\hline Dissolved oxygen $\left(\mathrm{mg} \cdot \mathrm{L}^{-1}\right)$ & $8.0(0.5)$ & $8.0(0.5)$ & - \\
\hline $\mathrm{pH}$ & $7.3(0.1)$ & $7.4(<0.1)$ & - \\
\hline Conductivity $\left(\mu \mathrm{S} \cdot \mathrm{cm}^{-1}\right)$ & $163(19)$ & $264(54)^{*}$ & 92 \\
\hline Temperature $\left({ }^{\circ} \mathrm{C}\right)$ & $18.4(1.6)$ & $18.8(1.5)$ & - \\
\hline
\end{tabular}

*Asterisks denote a significant difference between upstream and downstream mean values for the same water quality parameter; ${ }^{\dagger}$ Least significant diference at the 0.05 level (LSD 0.05$) ;{ }^{\dagger \dagger}$ Parameter also had significant site $\mathrm{x}$ flow regime interaction. 
Table 4. Summary of the effect of flow regime (i.e., Low, Medium, and High), averaged across sites, on water quality parameters measured upstream and downstream of the wastewater treatment plant discharge into the White river in Fayetteville, AR. Mean values are reported with standard errors in parentheses.

\begin{tabular}{|c|c|c|c|c|}
\hline \multirow{2}{*}{ Water quality parameter } & \multicolumn{3}{|c|}{ Flow regime } & \multirow{2}{*}{ LSD $_{0.05}+$} \\
\hline & Low $^{\dagger}$ & Medium $^{\dagger}$ & High $^{\dagger}$ & \\
\hline Nitrate $\left(\mathrm{mg} \cdot \mathrm{L}^{-1}\right)$ & $2.5(1.0) \mathrm{a}^{\ddagger}$ & $0.7(0.2) \mathrm{b}$ & $0.4(0.1) \mathrm{b}$ & $1.5^{\pi}$ \\
\hline Nitrite $\left(m g \cdot L^{-1}\right)$ & $0.01(0.01)$ & $0.01(<0.01)$ & $0.01(<0.01)$ & - \\
\hline Ammonium $\left(\mathrm{mg} \cdot \mathrm{L}^{-1}\right)$ & $0.1(<0.1)$ & $0.1(<0.1)$ & $0.1(<0.1)$ & - \\
\hline Total nitrogen $\left(\mathrm{mg} \cdot \mathrm{L}^{-1}\right)$ & $2.6(1.0) \mathrm{a}$ & $0.8(0.2) \mathrm{b}$ & $0.5(0.1) \mathrm{b}$ & $1.32^{\star}$ \\
\hline Soluble reactive phosphorus $\left(\mathrm{mg} \cdot \mathrm{L}^{-1}\right)$ & $0.03(0.01)$ & $0.01(<0.01)$ & $0.02(0.01)$ & - \\
\hline Total phosphorus $\left(\mathrm{mg} \cdot \mathrm{L}^{-1}\right)$ & $0.07(0.01) \mathrm{a}$ & $0.03(0.01) \mathrm{b}$ & $0.04(0.01) \mathrm{b}$ & $0.02^{\pi}$ \\
\hline Turbidity (NTU) & $7.2(0.8) \mathrm{a}$ & $14.4(2.3) \mathrm{ab}$ & $18.2(3.7) \mathrm{b}$ & 7.3 \\
\hline Total organic carbon $\left(\mathrm{mg} \cdot \mathrm{L}^{-1}\right)$ & $3.9(0.4) \mathrm{a}$ & $2.3(0.2) \mathrm{b}$ & $1.7(0.2) \mathrm{b}$ & 0.8 \\
\hline Chloride $\left(\mathrm{mg} \cdot \mathrm{L}^{-1}\right)$ & $21.3(6.0) \mathrm{a}$ & $7.2(0.7) \mathrm{b}$ & $5.9(0.5) \mathrm{b}$ & $7.9^{\pi}$ \\
\hline Dissolved oxygen $\left(\mathrm{mg} \cdot \mathrm{L}^{-1}\right)$ & $6.1(0.3) \mathrm{a}$ & $8.2(0.4) b$ & $10.0(0.6) \mathrm{c}$ & 1.3 \\
\hline $\mathrm{pH}$ & $7.4(0.1)$ & $7.2(0.1)$ & $7.3(0.1)$ & - \\
\hline Conductivity $\left(\mu \mathrm{S} \cdot \mathrm{cm}^{-1}\right)$ & $359(69) \mathrm{a}$ & $156(13) \mathrm{b}$ & $111(4.6) b$ & 113 \\
\hline Temperature $\left({ }^{\circ} \mathrm{C}\right)$ & $21.8(1.9)$ & $17.7(1.3)$ & $15.9(2.0)$ & - \\
\hline
\end{tabular}

†Flow regime categories are defined as follows: Low $\left(<2.0 \mathrm{~m}^{3} \mathrm{~s}^{-1}\right)$, Medium $\left(2.0-6.0 \mathrm{~m}^{3} \mathrm{~s}^{-1}\right)$, and High $\left(>6.0 \mathrm{~m}^{3} \mathrm{~s}^{-1}\right)$; $\dagger \dagger$ Least significant difference at the 0.05 level $\left(\mathrm{LSD}_{0.05}\right)$; $\$$ Means followed by difference letters in the same row are different at the 0.05 level; Parameter also had significant site $\mathrm{x}$ flow regime interaction.

er than that of Site 1 (Table 1) and ranged from 95 to $1118 \mu \mathrm{S} \cdot \mathrm{cm}^{-1}$.

\subsection{Nutrient Retention, Export and Net Uptake}

The White River showed variable retention or export of nutrients across sampling dates and between constituents when reach-level inputs and outputs were evaluated using the retention-coefficient approach. The various forms of $\mathrm{N}$ showed retention coefficients ranging from a low of -2.42 to a high of 0.96 for $\mathrm{NH}_{4}-\mathrm{N}, \mathrm{NO}_{3}-\mathrm{N}+\mathrm{NO}_{2}-\mathrm{N}$, and $\mathrm{TN}$. Only $\mathrm{NH}_{4}-\mathrm{N}$ had an average retention coefficient that was significantly different (i.e., greater) than zero ( $p$ $=0.04$ ), suggesting $\mathrm{NH}_{4}-\mathrm{N}$ was generally retained or transformed through the study reach. The other forms of $\mathrm{N}$ were, on average, just transported downstream without retention or transformation. The retention coefficients for $\mathrm{NO}_{3}-\mathrm{N}+\mathrm{NO}_{2}-\mathrm{N}$ and TN were highly correlated $(r=0.99$, $p<0.001$ ), which is not surprising since $\mathrm{NO}_{3}-\mathrm{N}$ made up a large portion on the TN pool. However, $\mathrm{NH}_{4}-\mathrm{N}$ retention coefficients were not correlated $(p>0.10)$ with the retention coefficients of other $\mathrm{N}$ forms within the White River.

Phosphorus retention coefficients within the study reach were just as variable as $\mathrm{N}$ forms, ranging from -1.19 to 0.94 for SRP and -0.92 to 0.94 for TP. On average, retention coefficients did not differ from zero, suggesting that minimal retention was occurring. Retention coefficients for SRP and TP were significantly correlated $(r=0.64, p<0.01)$, likely because SRP made up a large portion of TP in the White River. Total N and P retention coefficients were also correlated $(r=0.52, p=$
0.02 ), suggesting that retention of these two nutrients might be coupled within this study reach.

The calculations of net uptake lengths were not biased by flow through alluvial gravel within the study reach, as may have been the case for retention coefficients that were based on reach-level inputs and outputs. Calculated $\mathrm{S}_{\text {NET }}$ values showed trends (increasing, decreasing, or no significant change) in the downstream direction. Net uptake lengths for SRP were significant $(p<0.10)$ on five sample dates within the study period, ranging from -8.7 to $7.9 \mathrm{~km}$. Overall, little retention of SRP was occurring within the fluvial channel of the White River, suggesting that the study reach was not a consistent sink for SRP. Across these five sampling dates, SRP $\mathrm{S}_{\mathrm{NET}}$ was positively correlated to Site 2 SRP concentration $(r$ $=0.927, p=0.02)$ suggesting that as the concentration of SRP at Site 2 increased, $S_{\text {NET }}$ also increased. The study reach acted as a source of SRP when the effects of the effluent discharge were minimal and observed concentrations at Site 2 were $0.06 \mathrm{mg} \cdot \mathrm{L}^{-1}$ or less. Net uptake lengths for SRP were not correlated with any other physio-chemical property measured in the White River. Table 6 summarizes $\mathrm{V}_{\text {F-NET }}$ and $\mathrm{U}_{\mathrm{NET}}$ values for SRP within the White River.

Net uptake lengths for $\mathrm{NO}_{3}-\mathrm{N}$ were significant on 10 sampling dates, ranging from -22.1 to $13.1 \mathrm{~km}$. Similar to SRP $\mathrm{S}_{\mathrm{NET}}, \mathrm{NO}_{3}-\mathrm{N} \mathrm{S}_{\mathrm{NET}}$ had some sampling dates showing net retention within the study reach and others suggesting net export from the study reach. The net export could be explained by nitrification of reduced $\mathrm{N}$ forms within the fluvial channel, whereas the net retention 
Table 5. Summary of water quality characteristics averaged across all flow regimes and the five downstream study sites in the White river downstream of the wastewater treatment plant discharge in Fayetteville, AR.

\begin{tabular}{cccc}
\hline Water quality parameter & Minimum & Maximum & Average \\
\hline Nitrate $\left(\mathrm{mg} \cdot \mathrm{L}^{-1}\right)$ & 0.2 & 12.5 & 3.2 \\
Nitrite $\left(\mathrm{mg} \cdot \mathrm{L}^{-1}\right)$ & $<0.01$ & 0.14 & 0.04 \\
Ammonium $\left(\mathrm{mg} \cdot \mathrm{L}^{-1}\right)$ & 0.01 & 0.88 & 0.19 \\
Total nitrogen $\left(\mathrm{mg} \cdot \mathrm{L}^{-1}\right)$ & 0.3 & 11.0 & 3.1 \\
Soluble reactive phosphorus $\left(\mathrm{mg} \cdot \mathrm{L}^{-1}\right)$ & $<0.01$ & 0.32 & 0.07 \\
Total phosphorus $\left(\mathrm{mg} \cdot \mathrm{L}^{-1}\right)$ & $<0.01$ & 0.36 & 0.10 \\
Turbidity $\left(\mathrm{NTU} \mathrm{U}^{*}\right)$ & 4.9 & 49.9 & 22.1 \\
Total organic carbon $\left(\mathrm{mg} \cdot \mathrm{L}^{-1}\right)$ & 0.9 & 7.5 & 3.8 \\
Chloride $\left(\mathrm{mg} \cdot \mathrm{L}^{-1}\right)$ & 4.8 & 76.7 & 30.4 \\
Dissolved oxygen $\left(\mathrm{mg} \cdot \mathrm{L}^{-1}\right)$ & 5.1 & 13.8 & 8.8 \\
pH & 6.4 & 9.2 & 7.6 \\
Conductivity $(\mu \mathrm{S} \cdot \mathrm{cm}$ & & 1118 & 330 \\
Temperature $\left({ }^{\circ} \mathrm{C}\right)$ & 95 & 32.9 & 19.2 \\
\hline
\end{tabular}

* Nephalometric turbidity units (NTU).

Table 6. Summary statistics for mass transfer coefficients ( $\left.V_{\text {F-NET }}\right)$ and uptake rates ( $\left.U_{\text {NET }}\right)$ for soluble reactive phosphorus (SRP), ammonium-nitrogen ( $\left.\mathrm{NH}_{4}-\mathrm{N}\right)$, and nitrate-nitrogen ( $\mathrm{NO}_{3}-\mathrm{N}$ ) on sampling dates that demonstrated significant net nutrient uptake or release in the study reach of the White River, AR downstream of the wastewater treatment plant.

\begin{tabular}{|c|c|c|c|c|c|c|c|}
\hline \multirow[b]{2}{*}{ Nutrient } & \multirow[b]{2}{*}{$\mathrm{NPPPP}^{\dagger}$} & \multicolumn{3}{|c|}{ VRRRR $_{\text {F-NETRRRR (m/s) }}$} & \multicolumn{3}{|c|}{$\mathrm{URRRR}_{\text {NET }}$ RRRR (mg/mPPPP $\left.{ }^{2} \mathrm{PPPP} / \mathbf{s}\right)$} \\
\hline & & Min & Max & Average & Min & Max & Average \\
\hline SRP & 5 & $-7.3 \mathrm{E}-06$ & $2.7 \mathrm{E}-05$ & $6.9 \mathrm{E}-06$ & $-4.4 \mathrm{E}-04$ & $2.7 \mathrm{E}-03$ & $7.7 \mathrm{E}-04$ \\
\hline $\mathrm{NH}_{4}-\mathrm{N}$ & 6 & $3.6 \mathrm{E}-06$ & $4.0 \mathrm{E}-05$ & $1.5 \mathrm{E}-05$ & $2.5 \mathrm{E}-02$ & $4.1 \mathrm{E}-01$ & $1.6 \mathrm{E}-01$ \\
\hline $\mathrm{NO}_{3}-\mathrm{N}$ & 10 & $-1.1 \mathrm{E}-05$ & $2.3 \mathrm{E}-05$ & $5.8 \mathrm{E}-06$ & $-1.9 \mathrm{E} 00$ & 19.4E00 & 2.6Е00 \\
\hline
\end{tabular}

${ }^{\dagger}$ The number of sampling dates in which nutrient uptake length $\left(\mathrm{S}_{\mathrm{NET}}\right)$ was significant at $p<0.1$.

occurred when biological uptake and denitrification exceeded nitrification rates. Net uptake lengths for $\mathrm{NO}_{3}-\mathrm{N}$ were only correlated with turbidity at Site $2(r=0.65, p=$ 0.04 ), whereas no other measured physio-chemical property was related to $\mathrm{NO}_{3}-\mathrm{N} \mathrm{S}_{\mathrm{NET}}$. Table 6 summarizes $\mathrm{V}_{\mathrm{F}-\mathrm{NET}}$ and $\mathrm{U}_{\mathrm{NET}}$ values for $\mathrm{NO}_{3}-\mathrm{N}$ across the sampling dates.

Net uptake lengths for $\mathrm{NH}_{4}-\mathrm{N}$ displayed less variation than that for SRP or $\mathrm{NO}_{3}-\mathrm{N} \mathrm{S}_{\mathrm{NET}}$ across the sampling dates, ranging from 5.0 to $14.8 \mathrm{~km}$. When $\mathrm{S}_{\mathrm{NET}}$ was significant, uptake lengths were long, but positive, suggesting that $\mathrm{NH}_{4}-\mathrm{N}$ was retained, albeit not efficiently, within the White River downstream from the effluent discharge. Net uptake lengths for $\mathrm{NH}_{4}-\mathrm{N}$ were not significantly correlated to any physio-chemical property measured downstream from the effluent discharge during this study. Table 6 summarizes $\mathrm{V}_{\mathrm{F}-\mathrm{NET}}$ and $\mathrm{U}_{\mathrm{NET}}$ values for $\mathrm{NH}_{4}-\mathrm{N}$ across the sampling dates.

\subsection{Comparison to Other Studies}

Effluent chemistry often differs greatly from that in receiving aquatic systems [36], and the effluent discharge at the White River near Fayetteville, Arkansas had a significant influence on water chemistry and nutrient transport. Despite the large size of the White River (i.e., $5^{\text {th }}$ order), this effluent discharge at times made up a substantial portion of flow within the study reach during relatively dry summers. Overall, the influence of the effluent discharge on water chemistry was observable across all flow regimes as defined in this study, but was most profound during low-flow conditions $\left(<2 \mathrm{~m}^{3} \cdot \mathrm{s}^{-1}\right)$. Other studies have shown that effluent discharges influence stream water chemistry when the stream flow is dominated by WWTP inputs [7-9,32].

Phosphorus generally travels long distances downstream from effluent discharges before significant retention occurs, and this observation is consistent across streams receiving effluent discharge in the Ozark Highlands $[6,7,32]$ and others throughout the USA [12] and the world $[8,9]$. When significant net retention occurs, $\mathrm{S}_{\mathrm{NET}}$ distances can reach up to $85 \mathrm{~km}$ [12], but most $\mathrm{S}_{\text {NET }}$ SRP lengths is less than $20 \mathrm{~km}[6,7,12,32]$. The effects of effluent discharges on SRP concentrations and transport likely vary with how much the effluent domi- 
nates a receiving stream and how much effluent changes concentrations in the receiving stream. At the White River, TP concentrations and transport were similar to SRP, because TP was largely in the soluble-reactive form.

However, some consistencies occur across streams that are effluent dominated to larger rivers where effluents are not a major proportion of discharge within the fluvial channel. For example, both the White River (this study) and other effluent-dominated streams [7,12,32] showed net release of SRP from within the study reaches. Haggard et al. [7] suggested that SRP release occurs when effluent $\mathrm{P}$ concentrations are relatively low, and the SRP concentration in the receiving stream is less than that associated with the sediment equilibrium $\mathrm{P}$ concentrations $\left(\mathrm{EPC}_{0}\right)$. Ekka et al. [32] showed that sediment $\mathrm{EPC}_{0}$ are strongly influenced by effluent $\mathrm{P}$ inputs, and that dramatic changes in $\mathrm{EPC}_{0}$ may occur with changes in effluent $\mathrm{P}$ concentrations. It is likely that something similar is happening within the White River downstream of the WWTP input. However, sediment-P interactions might be more complex in the White River because this stream is more turbid relative to other Ozark streams. Thus, dissolved inorganic P (i.e., SRP) transport, retention and release through the White River might be more complex, for a variety of reasons, than that observed in less turbid streams within the Ozark Highlands.

The White River was less efficient at $\mathrm{NH}_{4}-\mathrm{N}$ retention compared to other smaller streams receiving effluent discharge, because $\mathrm{NH}_{4}-\mathrm{N} \mathrm{S}_{\mathrm{NET}}$ was $5 \mathrm{~km}$ or longer at the White River compared to less than $1.5 \mathrm{~km}$ in smaller systems (eg., Columbia Hollow; Figure 5) [7]. However, the observation that these stream reaches were a sink for $\mathrm{NH}_{4}-\mathrm{N}$ (i.e., $\mathrm{S}_{\mathrm{NET}}$ was positive on all sampling dates) was consistent across small to large river systems. It is likely that biological transformation (i.e., nitrification) was the mechanism responsible for $\mathrm{NH}_{4}-\mathrm{N}$ retention, but suspended and stream-bed sediments can also adsorb $\mathrm{NH}_{4}-\mathrm{N}$ from the water column. In contrast, Gibson and Meyer [12] showed that $\mathrm{NH}_{4}-\mathrm{N}$ release occurred within the Chattahoochee River downstream from multiple effluent discharges (Figure 5).

The transport of $\mathrm{NO}_{3}-\mathrm{N}$ downstream from effluent discharges is complex, because nitrification of reduced $\mathrm{N}$ forms within the effluent and the fluvial channel can result in increasing $\mathrm{NO}_{3}-\mathrm{N}$ concentrations with downstream distance $[7,8]$. In the White River, $\mathrm{NO}_{3}-\mathrm{N}$ was significantly retained on half of the sampling dates, while the other dates showed increases in dilution-corrected $\mathrm{NO}_{3}-\mathrm{N}$ concentrations downstream. The observed $\mathrm{NO}_{3}-\mathrm{N}$ dynamics in the White River match that observed at many other streams receiving effluent discharge (Figure 5), where net $\mathrm{NO}_{3}-\mathrm{N}$ release occurs as often as net
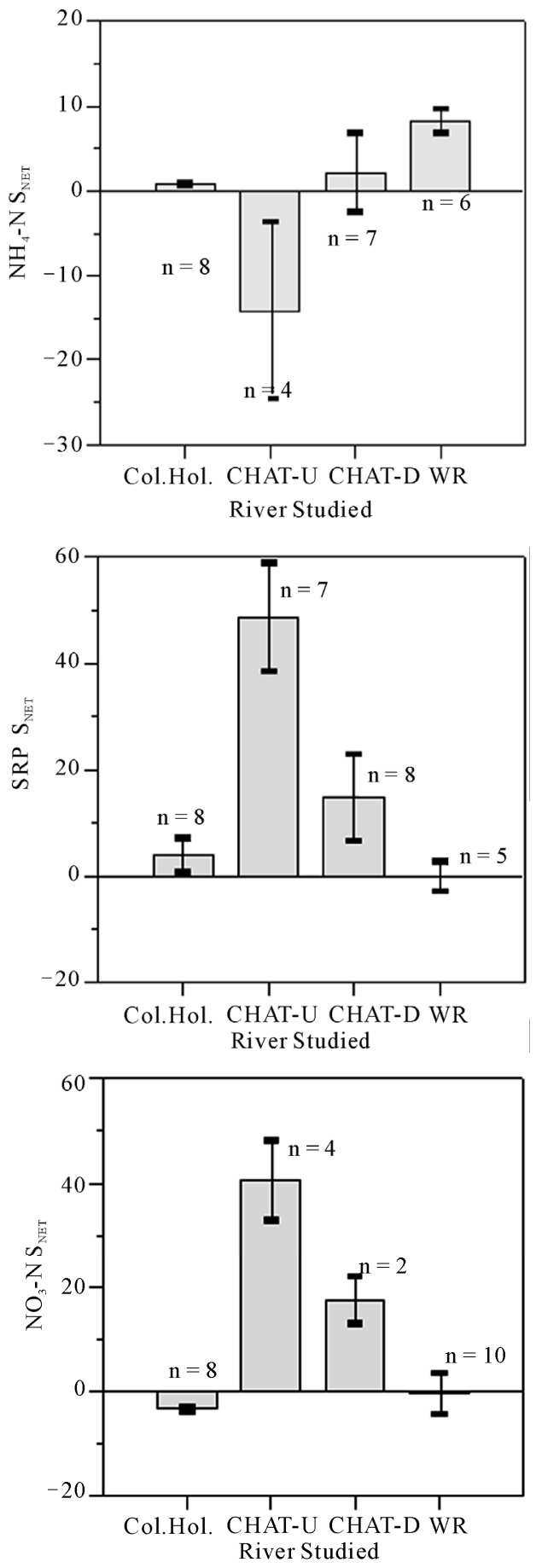

Figure 5. Comparison of net nutrient uptake lengths $\left(\mathrm{S}_{\mathrm{NET}}\right)$ for ammonium-nitrogen $\left(\mathrm{NH}_{4}-\mathrm{N}\right)$, nitrate-nitrogen $\left(\mathrm{NO}_{3}-\mathrm{N}\right)$, and soluble reactive phosphorus (SRP) from two previous studies examining wastewater treatment plant (WWTP) effluent receiving streams to that from the current study. Data are presented for Columbia Hollow (CH), Arkansas [7] and the Chattahoochee River-upstream study reach (CHAT-U) and downstream study reach (CHAT-D), Georgia [12]. The standard error about the mean and the number of observations (n) in each of the studies are also reported. 
$\mathrm{NO}_{3}-\mathrm{N}$ retention $[8,12]$.

The observation that the White River downstream from this effluent discharge does not efficiently retain nutrients, either SRP or $\mathrm{NO}_{3}-\mathrm{N}$, is important because the end of this study reach is the headwaters of Beaver Lake. Thus, this essentially means that nutrient inputs from this WWTP travel kilometer-scale distances downstream to the reservoir providing drinking water for northwest Arkansas. The effluent discharge might actually be influencing primary productivity in the headwaters of Beaver Lake because sestonic chlorophyll-a concentrations generally increase with $\mathrm{N}$ and $\mathrm{P}$ supply [37]. However, the WWTP effluent discharge contributes less than $10 \%$ of the annual inputs of TN or TP to Beaver Lake from its watershed [38]. Nutrient transport in streams downstream effluent discharges often depends on drought conditions [39], and the relative contribution of annual inputs from this WWTP to Beaver Lake will likely be greater during years where annual discharge is less.

\section{Conclusions}

The WWTP discharge into the White River made up a small fraction of the total river discharge, and the immediate dilution of the effluent was apparent by the observed changes in water quality during low river discharge. This effluent discharge had a significant impact on nutrient concentrations, despite its relatively low contribution to river discharge. However, longitudinal patterns in nutrient concentrations downstream from the effluent discharge were not as consistent as reported previously for smaller-order rivers where the effluent made up a relatively larger proportion of river discharge. Nutrient retention coefficients were highly variable, and suggested that $\mathrm{NO}_{3}-\mathrm{N}+\mathrm{NO}_{2}-\mathrm{N}$ and SRP were, on average, not retained within the study reach. However, $\mathrm{NH}_{4}-\mathrm{N}$ was significantly retained within the study, on average, when evaluating reach level inputs and outputs. Since little nutrient retention occurred in the White River downstream from this effluent discharge, the headwaters of Beaver Lake are likely directly influenced by the WWTP evaluate in this study. The WWTP has relatively low nutrient concentrations in its effluent discharge, but its continual discharge of nutrients to the White River has resulted in little retention within the study reach. Thus, any changes to the effluent nutrient concentrations or loading would likely influence the headwaters of Beaver Lake.

\section{Acknowledgements}

Beaver Water District and staff are gratefully acknowledged for providing the resources to conduct this study. Mindi Crosswhite, Raymond Avery, and Rusty Tate provided invaluable field sampling support and expertise and Cindy Harp assisted with timely laboratory analyses.

\section{REFERENCES}

[1] Arkansas Department of Environmental Quality, “Arkansas's 2008 303(d) List (List of Impaired Waterbodies)," 2008. Internet Available:

http://www.adeq.state.ar.us/water/branch_planning/pdfs/3 03d_list_2008.pdfT

[2] D. R. Edwards and T. C. Daniel, "Effects of Poultry Litter Application Rate and Rainfall Intensity on Quality of Runoff from Fescue Plots," Journal of Environmental Quality, Vol. 22, No. 2, 1993, pp. 361-365. doi: $10.2134 /$ jeq1993.00472425002200020017x

[3] D. R. Edwards, P. A. Moore, J. F. Murdoch and T. C. Daniel, "Quality of Runoff from Four Northwest Arkansas Pasture Fields Treated with Organic and Inorganic Fertilizer," Transactions of the ASAE, Vol. 39, No. 5, 1995, pp. 1689-1696.

[4] T. J. Sauer, P. A. Moore, G. L. Wheeler, C. P. West, T. C. Daniel and D. J. Nichols, "Runoff Water Quality from Poultry Litter-Treated Pasture and Forest Sites," Journal of Environmental Quality, Vol. 29, No. 2, 2000, pp. 515-521. doi:10.2134/jeq2000.00472425002900020020x

[5] B. C. Menjoulet, K. R. Brye, A. L. Pirani, B. E. Haggard and E. E. Gbur, "Runoff Water Quality from Broiler-Litter-Amended Tall Fescue in Response to Natural Precipitation in the Ozark Highlands," Journal of Environmental Quality, Vol. 38, No. 3, 2009, pp. 1005-1017. doi:10.2134/jeq2008.0140

[6] B. E. Haggard, D. E. Storm and E. H. Stanley, "Effect of a Point Source Input on Stream Nutrient Retention," Journal of the American Water Resources Association, Vol. 37, No. 5, 2001, pp. 1291-1299. doi:10.1111/j.1752-1688.2001.tb03639.x

[7] B. E. Haggard, E. H. Stanley and D. E. Storm, "Nutrient Retention in a Point-Source-Enriched Stream," Journal of the North American Benthological Society, Vol. 24, No. 1, 2005, pp. 29-47.

doi:10.1899/0887-3593(2005)024<0029:NRIAPS $>2.0 . C$ $\underline{\mathrm{O} ; 2}$

[8] E. Marti, J. Autmatell, L. Godé, M. Poch and F. Sabater, "Nutrient Retention Efficiency in Streams Receiving Inputs from Wastewater Treatment Plants," Journal of Environmental Quality, Vol. 33, 2004, pp. 285-293. doi:10.2134/jeq2004.0285

[9] G. C. Merseberger, E. Martí and F. Sabater, "Net Changes in Nutrient Concentrations below a Point Source Input in Two Streams Draining Catchments with Contrasting Land Uses," Science of the Total Environment, Vol. 347, No. 1-3, 2005, pp. 217-229. doi:10.1016/j.scitotenv.2004.12.022

[10] B. Gücker, M. Brauns and M. T. Pusch, "Effects of Wastewater Treatment Plant Discharge on Ecosystem Structure and Function of Lowland Streams," Journal of the North American Benthological Society, Vol. 5, 2006, pp. 313-329.

[11] S. Treese, T. Meixner and J. F. Hogan, "Clogging of an 
Effluent Dominated Semiarid River: A Conceptual Model of Stream-Aquifer Interactions," Journal of the American Water Resources Association, Vol. 45, No. 4, 2010, pp. 1047-1062. doi:10.1111/j.1752-1688.2009.00346.x

[12] C. A. Gibson and J. L. Meyer, "Nutrient Uptake in a Large Urban River," Journal of the American Water Resources Association, Vol. 43, No. 3, 2007, pp. 576-587. doi:10.1111/j.1752-1688.2007.00041.x

[13] S. R. Femmer, "National Water-Quality Assessment Program Ozark Plateaus Biology Study," 1995. Internet Available: http://mo.water.usgs.gov/fact_sheets/biology.htm

[14] K. R. Brye and C. P. West, "Grassland Management Effects on Soil Surface Properties in the Ozark Highlands," Soil Science, Vol. 170, 2005, pp. 63-73. doi:10.1097/00010694-200501000-00008

[15] H. D. Scott and L. B. Ward, "MLRA 116A Ozark Highlands," 2006. Internet Available: http://soilphysics.okstate.edu/S257/book/mlra116a/index. html

[16] National Agricultural Statistics Service-United States Department of Agriculture, "Poultry-Production and Value, 2002 Summary," 2003. Internet Available: http://www.usda.mannlib.cornell.edu/usda/nass/PoulProd Va-04-29-2003.pdf

[17] T. J. T. Sims and D. C. Wolf, "Poultry Waste Management: Agricultural and Environmental Issues," Advances in Agronomy, Vol. 52, 1994, pp. 1-83. doi:10.1016/S0065-2113(08)60621-5

[18] University of Arkansas Cooperative Extension Service, "Improving Poultry Litter Management and Carcass Disposal," 2002. Internet Available: http://www.arnatural.org/environmental_management/eq uip4/fact $8 . h t m l$

[19] N. A. Slaton, K. R. Brye, M. B. Daniels, T. C. Daniel, R. J. Norman and D. M. Miller, "Nutrient Input and Removal Trends for Agricultural Soils in Nine Geographic regions in Arkansas," Journal of Environmental Quality, Vol. 33, No. 5, 2004, pp. 1606-1615. doi: $10.2134 /$ jeq2004.1606

[20] United States Census Bureau, "2007 Population Estimates," 2010. Internet Available: http://www.census.gov

[21] Arkansas Department of Environmental Quality, "West Fork White River Watershed Data Inventory and Nonpoint Source," 2004. Internet Available: http://www.adeq.state.ar.us/water/pdfs/West_Fork_White _River_Watershed.pdf

[22] National Oceanic and Atmospheric Administration, "Washington County, Arkansas Climatology," 2009. Internet Available http://www.srh.noaa.gov/tsa/?n=climo_washington

[23] United States Geological Survey, "Precipitation Data for Site Number 07048600," 2006. Internet Available: http://waterdata.usgs.gov/nwis/dv?cb_00045=on\&format $=$ html\&begin date $=2006-01-01$ \&end date $=2007-12-31 \&$ site_no $=07048600 \&$ referred_module $=$ sw

[24] United States Geological Survey, "USGS 07048600 White River near Fayetteville, AR Site Information,"
2006. Internet Available:

HTThttp://waterdata.usgs.gov/nwis/nwismap/?site_no $=07$ 048600\&agency_cd=usgs

[25] American Public Health Association-American Water Works Association-Water Environment Federation, "Standard Methods for the Examination of Water and Wastewater," $21^{\text {st }}$ Edition, American Public Health Association, Washington DC, 2005.

[26] American Society for Testing and Materials, "Annual Book of ASTM Standards," Vol. 11, No. 1, ASTM, Philadelphia, 2004.

[27] HACH Company, "DR/4000 Spectrophotometer Handbook," HACH, Loveland, 1996.

[28] J. D. Newbold, J. W. Elwood, R. V. O’Neill and A. L. Sheldon, "Measuring Nutrient Spiraling in Streams," Canadian Journal of Fisheries and Aquatic Sciences, Vol. 38, No. 7, 1981, pp. 860-863. doi:10.1139/f81-114

[29] United States Geological Survey, "River Discharge Data for Site Number 07048600," 2006. Internet Available: http://waterdata.usgs.gov/nwis/annual?referred_module $=\mathrm{s}$ w\&site_no $=07048600 \&$ por_07048600_2 $=278 \overline{52} 20,00060$, $2,1964, \overline{2} 010 \&$ start_dt $=196 \overline{4} \&$ end_dt $=2006 \&$ year_type $=$ W\&format $=$ html_table_format $=\overline{Y Y Y}$-MM-DD\& $\mathrm{rdb}$ _co mpresion=file\&submitted_form=parameter_selection_list

[30] FTN Associates, Ltd., "TMDLs for Turbidity for White River and West Fork, AR," 2006. Internet Available: http://www.adeq.state.ar.us/ftproot/Pub/WebDatabases/Perm itsOnline/NPDES/Tech/AR0022373 TMDLS\%20forT TH $\% 2$ Turbidity $\% 20$ for $\% 20$ White $\% 20$ River $\% 20$ and $\% 20$ West\%20Fork\%20White\%20River_20051031.pdf

[31] Environmental Protection Agency, "Ambient Water Quality Criteria Recommendations-Information Supporting the Development of State and Tribal Nutrient Criteria-Rivers and Streams in Nutrient Ecoregion XI," 2000. Internet Available:

http://water.epa.gov/scitech/swguidance/waterquality/stan dards/criteTHria/aqlife/pollutants/nutrient/upload/2007_0 9_27_criteria_nutrient_ecoregions_rivers_rivers_11.pdf

[32] S. A. Ekka, B. E. Haggard, M. D. Matlock and I. Chaubey, "Dissolved Phosphorus Concentrations and Sediment Interactions in Effluent-Dominated Streams," Ecological Engineering, Vol. 26, 2006, pp. 375-391. doi:10.1016/j.ecoleng.2006.01.002

[33] N. C. Brady and R. R. Weil, "The Nature and Properties of Soils," $13^{\text {th }}$ Edition, Prentice Hall, Upper Saddle River, New Jersey, 2002.

[34] A. L. Ludwig, "Periphytic Algae Nutrient Limitation in Streams Draining the Beaver Reservoir Basin, Northwest Arkansas, USA, 2005-2006," Master's Thesis, University of Arkansas, Fayetteville, 2007.

[35] T. H. Diehl and W. J. Wolfe, "Suspended-Sediment Concentration Regimes for Two Biological Reference Streams in Middle Tennessee," Journal of the American Water Resources Association, Vol. 46, No. 4, 2010, pp. 824-837. doi:10.1111/j.1752-1688.2010.00460.x

[36] R. O. Carey and K. W. Migliaccio, "Contribution of Wastewater Treatment Plant Effluents to Nutrient Dy- 
namics in Aquatic Systems: A Review," Environmental Management, Vol. 44, No. 2, 2009, pp. 205-217. doi:10.1007/s00267-009-9309-5

[37] B. E. Haggard, T. P. A. Moore Jr., T. C. Daniel and D. R. Edwards, "Trophic Conditions and Gradients of the Headwater Reaches of Beaver Lake, Arkansas," Proceedings of the Oklahoma Academy of Science, Vol. 79, 1999, pp. 73-84.

[38] B. E. Haggard, P. A. Moore Jr., I. Chaubey and E. H. Stanley, "Nitrogen and Phosphorus Concentrations and
Export from an Ozark Plateau Catchment in the United States," Biosystems Engineering, Vol. 86, No. 1, 2003, pp. 75-85. doi:10.1016/S1537-5110(03)00100-4

[39] J. Hur, M. A. Schlautman, T. Karanfil, J. Smink, H. Song, S. J. Klaine and J. C. Hayes, "Influence of Drought and Municipal Sewage Effluents on the Baseflow Water Chemistry of an Upper Piedmont River," Environmental Monitoring and Assessment, Vol. 132, No. 1-3, 2007, pp. 171-187. doi:10.1007/s10661-006-9513-1 